\title{
EFFECTS OF INTRAVENOUS CUPRIC SULPHATE ON HYPOPHYSIAL ACTIVITY IN THE FEMALE RAT
}

\author{
M. HIROI, K. STEVENS* AND R. GORSKI \\ Department of Anatomy and Brain Research Institute, \\ UCLA School of Medicine, Los Angeles, California 90024
}

(Received 16th April 1968)

\begin{abstract}
Summary. In normal cyclic female rats, an injection of $16 \mathrm{mg} \mathrm{CuSO}_{4} /$ $\mathrm{kg}$ induces pseudopregnancy (as determined by uterine traumatization) when given on the day of oestrus, or on the following day. Pentobarbital anaesthesia did not inhibit this effect of $\mathrm{CuSO}_{4}$. Pseudopregnancy, as determined by inhibition of the induction of vaginal cornification by exogenous oestrogen, was also induced by $\mathrm{CuSO}_{4}$ in anovulatory females, provided the injection was given from $6 \mathrm{hr}$ before, to $24 \mathrm{hr}$ after injection of human chorionic gonadotrophin. The latter was necessary since $\mathrm{CuSO}_{4}$ did not induce ovulation in forty experimentally produced anovulatory rats. Cupric sulphate injected on the day of vaginal prooestrus in normal females did not alter the incidence of spontaneous ovulation nor the number of ova shed. These data suggest an effect of copper ion in the rat on luteal regulatory mechanisms rather than on ovulatory mechanisms; the site of action cannot, however, be specified.
\end{abstract}

\section{INTRODUCTION}

In the oestrous rabbit, the intravenous injection of copper acetate induces both the ovulation of fertile ova (Suzuki \& Bialy, 1964; Staples \& Bialy, 1967) and pseudopregnancy (Fevold, Hisaw \& Greep, 1936). Although a direct effect of copper ion on the pituitary has been proposed (Fevold et al., 1936; Sawyer \& Markee, 1950), recent experiments on the implantation of microgram quantities directly in the hypothalamus or pituitary suggest a neural site of action of copper in the rabbit (Hiroi, Sugita \& Suzuki, 1965). The influence of this ion on the regulation of gonadotrophin secretion in the female rat, however, has not been investigated extensively. Dury \& Bradbury (1941, 1943) demonstrated that copper injection induces pseudopregnancy only in the oestrous female. The present study confirms this observation in normal cyclic female rats. In addition, the occurrence of ovulation and/or pseudopregnancy following cupric sulphate injection has been recorded in experimentally anovulatory rats.

* Present address: Research Department, Hess and Clark, Ashland, Ohio, U.S.A. 


\section{METHODS}

Sprague-Dawley rats were housed in a controlled environment of $14 \mathrm{hr}$ of light and $10 \mathrm{hr}$ of darkness per day. Daily vaginal smears were obtained at 08.00 hours and normal rats were required to exhibit three regular vaginal cycles in succession before selection for experimental use. A $1 \%$ unbuffered cupric sulphate $\left(\mathrm{CuSO}_{4}-5 \mathrm{H}_{2} \mathrm{O}\right)$ solution in physiological saline was prepared; the volume of solution injected was determined by the dose of cupric ion/body weight of the recipient rat.

In cyclic females, pseudopregnancy was established by the decidual reaction to uterine traumatization produced by looping two pieces of thread through the antimesometrial wall of the uterus on the 4th day of a continuing dioestrus. The rats were killed 5 days after uterine traumatization and the presence or absence of deciduomata was recorded. Pseudopregnancy was also investigated in female rats rendered anovulatory (determined by laparotomy and the persistence of vaginal cornification) by exposure to constant illumination. Ovulation was induced by the injection of 10 i.u. human chorionic gonadotrophin (HCG) and $\mathrm{CuSO}_{4}$ was injected at varying times before or after HGG. In order to avoid possible alterations in uterine capacity to develop deciduomata in rats in persistent vaginal oestrus, progesterone secretion was detected by treating the females daily with oestradiol benzoate, $1 \mu \mathrm{g}$, for 5 days beginning 5 or 6 days after HGG injection. Treatment with $1 \mu \mathrm{g}$ oestradiol benzoate induces vaginal cornification in the spayed female within 2 to 3 days. Females which did not display vaginal cornification in response to this treatment were therefore considered to be actively secreting progesterone (Jones \& Astwood, 1942).

Attempts were made to induce ovulation in rats rendered anovulatory in several ways: twenty-nine were injected with 10 to $30 \mu \mathrm{g}$ testosterone propionate on the 4th, 5th or 6th day of life; six were exposed to constant illumination; and five were subjected to electrolytic destruction of the preoptic region of the brain, or to anterior hypothalamic de-afferentation according to the technique described by Halász \& Gorski (1967). Before experimentation, laparotomy was performed to confirm the absence of corpora lutea which was indicated by constant vaginal cornification. The presence of corpora lutea in these ovaries at laparotomy 7 days after $\mathrm{CuSO}_{4}$ injection indicated that ovulation had occurred. Finally, $\mathrm{CuSO}_{4}$ was injected into the tail vein of normal cyclic rats (without anaesthesia) at various times on the day of vaginal prooestrus. The influence of this treatment on spontaneous ovulation was ascertained by removing the oviduct the following morning, and counting the tubal ova by transillumination.

\section{RESULTS}

\section{Pseudopregnancy studies}

Since $\mathrm{CuSO}_{4}$ is a toxic compound, the relationship between the lethal dose and the induction of pseudopregnancy was determined in eighty adult female oestrous rats (Table 1). Most of the rats given $\mathrm{CuSO}_{4}$ at a dose of $18 \mathrm{mg} / \mathrm{kg}$ or more died within $24 \mathrm{hr}$. However, all the rats given not more than $16 \mathrm{mg} / \mathrm{kg}$ 
survived. In addition, $16 \mathrm{mg} / \mathrm{kg}$ was sufficient $\mathrm{CuSO}_{4}$ to induce pseudopregnancy in all oestrous rats, whereas less than $12 \mathrm{mg} / \mathrm{kg}$ did not induce pseudopregnancy. The $16 \mathrm{mg} / \mathrm{kg}$ dose was used in subsequent experiments.

The data of Table 2 indicate that $\mathrm{CuSO}_{4}$ given on the day of vaginal oestrus or $24 \mathrm{hr}$ later was highly effective in inducing pseudopregnancy as judged by uterine deciduomal reactivity. However, $\mathrm{CuSO}_{4}$ given on the day of dioestrus or early pro-oestrus was essentially without effect. The very high

TABLE 1

MORTALITY AND PSEUDOPREGNANCY RATE AFTER CUSO INJEGTION IN NORMAL GYGLIC FEMALES ON THE DAY OF VAGINAL OESTRUS

\begin{tabular}{c|c|c|c|c}
\hline $\begin{array}{c}\text { Dose of } \\
\mathrm{CuSO} \\
(\mathrm{mg} / \mathrm{kg})\end{array}$ & $\begin{array}{c}\text { No. of } \\
\text { rats } \\
\text { injected }\end{array}$ & $\begin{array}{c}\text { No. } \\
\text { of } \\
\text { deaths }\end{array}$ & $\begin{array}{c}\text { No. of rats } \\
\text { showing } \\
\text { pseudopregnancy* }\end{array}$ & $\begin{array}{c}\% \text { of surviving } \\
\text { rats showing } \\
\text { pseudopregnancy }\end{array}$ \\
\hline 5 & 10 & 0 & 0 & 0 \\
10 & 10 & 0 & 0 & 0 \\
12 & 10 & 0 & 4 & 40 \\
14 & 10 & 0 & 6 & 60 \\
16 & 10 & 0 & 10 & 100 \\
18 & 10 & 5 & 5 & 100 \\
20 & 10 & 7 & 3 & - \\
22 & 10 & 10 & 0 & \\
\hline
\end{tabular}

* Determined by decidual reaction after uterine traumatization.

TABLE 2

RATE OF PSEUDOPREGNANGY* FOLLOWING GUSO ${ }_{4}$ INJECTION AT DIFFERENT STAGES OF THE OESTROUS GYCLE

\begin{tabular}{l|c|c|c|c|c}
\hline \multirow{4}{*}{ Treatment } & \multicolumn{5}{|c}{ Stage of vaginal cycle at injection } \\
\cline { 2 - 6 } & Di-oestrus & \multicolumn{2}{|c}{ Pro-oestrus } & Oestrus & Post-oestrus \\
& 08.00 hours & 08.00 hours & 17.00 hours & 08.00 hours & 08.00 hours \\
\hline CuSO $_{4}$ injection $\dagger$ & $1 / 16_{+}^{\ddagger}$ & $2 / 18$ & $5 / 14$ & $18 / 18$ & $12 / 15$ \\
Nembutal\$ and $\mathrm{CuSO}_{4}$ injection & $0 / 15$ & $0 / 11$ & $3 / 12$ & $14 / 14$ & $11 / 14$ \\
Nembutal & $0 / 14$ & $0 / 10$ & $0 / 12$ & $0 / 12$ & $0 / 12$ \\
\hline
\end{tabular}

* Determined by decidual reaction after uterine traumatization.

$+16 \mathrm{mg} / \mathrm{kg}$.

$¥$ Number pseudopregnant/number injected.

$\int 32 \mathrm{mg} / \mathrm{kg}$ given $20 \mathrm{~min}$ before $\mathrm{CuSO}_{4}$.

incidence of pseudopregnancy when $\mathrm{CuSO}_{4}$ was injected on the day of oestrus, or the following day, was not altered when the rats were anaesthetized with pentobarbital (Nembutal) shortly before copper injection (Table 2).

In female rats displaying anovulatory persistent vaginal oestrus due to constant environmental illumination, $\mathrm{CuSO}_{4}$ did not induce ovulation (see below). Therefore, in order to study the ability of copper ion to induce pseudopregnancy in these animals, it was necessary to induce ovulation with HGG. In this way it was possible to vary the time of injection of $\mathrm{CuSO}_{4}$ in relation to the time of HCG injection (Table 3). When copper was injected within $24 \mathrm{hr}$ 
after HCG injection almost all rats continued in vaginal di-oestrus in spite of daily oestrogen injection. When this metallic ion was injected $48 \mathrm{hr}$ after, or $12 \mathrm{hr}$ before HCG, pseudopregnancy was not observed consistently.

TABLE 3

RATE OF PSEUDOPREGNANCY* FOLLOWING HCG AND CUSO 4 ADMINISTRATION AT VARIOUS TIMES IN THE ANOVULATORY RAT UNDER CONSTANT ILLUMINATION

\begin{tabular}{|c|c|c|c|c|c|c|c|c|c|c|c|c|}
\hline \multirow[b]{2}{*}{$\begin{array}{l}\text { No. pseudo- } \\
\text { pregnant/no. } \\
\text { injected }\end{array}$} & $H C G$ & $\mathrm{CuSO}_{4}$ & \multicolumn{8}{|c|}{$\begin{array}{c}\mathrm{HCG}, \text { then } \mathrm{CuSO}_{4} \\
\text { after indicated interval }(h r)\end{array}$} & $\mathrm{Na}_{2} \mathrm{SO}_{4} \dagger$ & $\begin{array}{c}\mathrm{Na}_{2} \mathrm{SO}_{4} \\
\text { and } \\
\mathrm{HCG}\end{array}$ \\
\hline & $0 / 9$ & $0 / 6$ & $0 / 6$ & $2 / 6$ & $4 / 6$ & $5 / 6$ & $5 / 6$ & $5 / 6$ & $4 / 6$ & $0 / 6$ & $0 / 6$ & $0 / 6$ \\
\hline $\begin{array}{l}\% \text { Showing } \\
\text { pseudopregnancy }\end{array}$ & 0 & 0 & 0 & 33 & 67 & 83 & 83 & 83 & 67 & 0 & 0 & 0 \\
\hline
\end{tabular}

* Determined by the persistence of a di-oestrous vaginal smear in spite of daily injection of $1 \mu \mathrm{g}$ oestradiol benzoate.

$\dagger$ In these studies, the injection of $\mathrm{Na}_{2} \mathrm{SO}_{4}(16 \mathrm{mg} / \mathrm{kg})$ was utilized as a control procedure.

\section{Ovulation studies}

In normal females. The data presented in Table 4 demonstrate that $\mathrm{CuSO}_{4}$ injected at any of five different times on the day of vaginal pro-oestrus had no effect on the number of ova released by each ovulating rat. Nor was there any marked effect on the incidence of ovulation among these animals.

In anovulatory adult females. Cupric sulphate was injected into various preparations of anovulatory persistent oestrous rats: twenty-nine androgenized rats, three rats with a preoptic-anterior hypothalamic lesion, two rats after surgical transection of ovulatory neural pathways, and six rats housed under continuous illumination. Cupric sulphate did not induce ovulation in any of these forty rats.

\section{TABLE 4}

INGIDENGE OF OVULATION, AND NUMBER OF OVA SHED IN THE NORMAL RAT FOLLOWING INJEGTION OF CUSO 4 OR OF $\mathrm{Na}_{2} \mathrm{SO}_{4}$ AT VARIOUS TIMES ON DAX OF PRO-OESTRUS

\begin{tabular}{c|l|rrrrr}
\hline & & \multicolumn{5}{|c}{ Time on day of vaginal pro-oestrus } \\
Treatment & & 06.00 & 08.00 & 10.00 & 12.00 & 16.00 \\
\hline $\mathrm{Na}_{2} \mathrm{SO}_{4}$ injection & Incidence of ovulation* & $5 / 5$ & $5 / 5$ & $5 / 5$ & $5 / 5$ & $5 / 5$ \\
$(16 \mathrm{mg} / \mathrm{kg})$ & Average no. of ova/ovulating rat & $11 \cdot 4$ & $11 \cdot 0$ & $11 \cdot 4$ & 12.0 & $12 \cdot 6$ \\
\hline $\mathrm{CuSO}_{4}$ injection & Incidence of ovulation & $9 / 10$ & $7 / 10$ & $5 / 5$ & $5 / 5$ & $5 / 5$ \\
$(16 \mathrm{mg} / \mathrm{kg})$ & Average no. of ova/ovulating rat & 10.9 & $9 \cdot 9$ & $11 \cdot 8$ & 13.2 & $11 \cdot 4$ \\
\hline
\end{tabular}

* No. rats ovulating/no. injected.

\section{DISCUSSION}

In the rabbit, corpora lutea appear to function following ovulation whether ovulation is induced by sterile mating, exogenous gonadotrophin or copper ion 
(Everett, 1961). In the rat, however, ovulation and CL activation appear to be regulated separately (Everett, 1961). The present data demonstrate a rather selective action of intravenous $\mathrm{CuSO}_{4}$ on luteal function (presumably through hypophysial luteotrophin). Although progesterone secretion was readily induced by $\mathrm{CuSO}_{4}$ injections in oestrous cyclic females, and within $24 \mathrm{hr}$ of an injection of HCG in anovulatory rats which had been exposed to constant illumination, ovulation was not induced by $\mathrm{CuSO}_{4}$ in anovulatory females.

The confirmation that pseudopregnancy is induced only at oestrus supports the view that oestrogen facilitates this action of copper ion (Dury \& Bradbury, $1941,1943)$. On the other hand, the lack of effect of $\mathrm{CuSO}_{4} 12 \mathrm{hr}$ before or $48 \mathrm{hr}$ after HCG injection, and the studies of Nikitovitch-Winer \& Everett (1958), suggest that the presence of CL capable of responding to the hypophysial luteotrophin may also be a decisive factor. The observation that pentobarbital does not prevent the action of $\mathrm{CuSO}_{4}$ recalls the controversy about the site of action of copper ion in the rabbit. Barbiturates can block the ovulatory stimulus in the immature (Quinn \& Zarrow, 1964; Wagner \& Brown-Grant, 1965) or adult female (Everett \& Sawyer, 1950), and prevent the action of exogenous androgen in the neonatal female rat (Arai \& Gorski, 1968). In either case, however, the relevant site of action of the barbiturate is unknown. Therefore, although the lack of an effect of pentobarbital suggests that $\mathrm{CuSO}_{4}$ may act directly on the pituitary, one cannot dismiss the possibility that $\mathrm{CuSO}_{4}$ acts on a terminal step in the neural mechanism distal to pentobarbital. In addition, it is possible that the action of $\mathrm{CuSO}_{4}$ persists beyond the duration of effective anaesthesia.

Although $\mathrm{CuSO}_{4}$ does not induce ovulation in the rat as in the rabbit, these negative findings are not surprising considering the inhibitory influence that the hypothalamus exerts over luteotrophin secretion in the rat (Everett; 1961). In fact, a non-specific action of copper ion which depresses hypothalmic function might be expected to induce pseudopregnancy, and also block ovulation. This is not the case, however, since $\mathrm{CuSO}_{4}$ administration at different times on the day of vaginal pro-oestrus did not interfere with the neural stimulus for ovulation or its effectiveness, since both the incidence of ovulation and the number of ova shed were unaltered.

Therefore, although we cannot specify whether $\mathrm{CuSO}_{4}$ inhibits hypothalamic function or directly stimulates pituitary secretion, its effects appear to be rather specific to a luteotrophin system. The lack of ovulation argues against a nonspecific direct stimulatory effect on the pituitary, and the occurrence of normal ovulation in pro-oestrous rats argues against a non-specific inhibition of the hypothalamus.

\section{ACKNOWLEDGMENTS}

This work was supported by USPHS grant number HD-01182, and by a Training Grant from the Ford Foundation. M.H. had a postdoctoral Research Fellowship of the Ford Foundation, on leave from the Department of Obstetrics and Gynecology, Niigata University School of Medicine, Niigata, Japan. K.S. acknowledges a postdoctoral Research Fellow of the USPHS (HD-21,356). 


\section{REFERENCES}

ARAI, Y. \& Gorskr, R. A. (1968) The critical exposure time for androgenization of the developing hypothalamus in the female rat. Endocrinology, 82, 1010.

DuRY, A. \& BRADBURY, J. T. (1941) Copper-induced pseudopregnancy in the adult estrous rat. Am. 7. Physiol. 135, 587.

Dury, A. \& Bradbury, J. T. (1943) Copper-induced pseudopregnancy facilitated by pretreatment with estrogen. Am. F. Physiol. 139, 135.

Everet, J. W. (1961) The mammalian female reproductive cycle and its controlling mechanisms. In: Sex and Internal Secretions, Vol. 1. Ed. W. C. Young. Williams \& Wilkins, Baltimore.

Everetr, J. W. \& SAWYer, C. H. (1950) A 24-hour periodicity in the "LH-release apparatus" of female rats, disclosed by barbiturate sedation. Endocrinology, 47, 198.

Fevold, H. L., Hisaw, F. L. \& Greep, R. (1936) Augmentation of the gonad stimulating action of pituitary extracts by inorganic substances, particularly copper salts. Am. J. Physiol. 117, 68.

HaLÁsz, B. \& GoRski, R. A. (1967) Gonadotrophic hormone secretion in female rats after partial or total interruption of neural afferents to the medial basal hypothalamus. Endocrinology, 80, 608.

Hrror, M., Sugrta, S. \& Suzuki, M. (1965) Ovulation induced by implantation of cupric sulfate into the brain of the rabbit. Endocrinology, 77, 963.

Jonks, G. E. S. \& Astwood, E. B. (1942) The physiological significance of the estrogen-progesterone ratio on vaginal cornification in the rat. Endocrinology, 30, 295.

Nixitovitch-Winer, M. \& EvereTt, J. W. (1958) Comparative study of luteotrophin secretion by hypophysial autotransplants in the rat. Effects of site and stages of the estrus cycle. Endocrinology, 62, 522.

QUinN, D. L. \& ZARRow, M. X. (1964) Inhibition of pregnant mare's serum-induced ovulation in the immature rat. Endocrinology, 74, 309.

SAWYeR, G. H. \& MARKEE, J. E. (1950) The differential mechanisms by which picrotoxin and copper acetate induce ovulation in the rabbit. Endocrinology, 46, 177.

Staples, R. E. \& Bialy, G. (1967) Rabbit zygote transport and development following various methods of ovulation induction. Endocrinology, 81, 400.

Suzuki, M. \& Bialy, G. (1964) Fertilizability of copper-ovulated rabbit ova. Endocrinology, 75, 288.

WAGNER, J. W. \& BRown-Grant, K. (1965) Studies on the time of luteinizing hormone release in gonadotrophin-treated immature rats. Endocrinology, 76, 958. 